\title{
Aversion to a sure loss: turning investors into gamblers*
}

\author{
Miroslav Ferenčak ${ }^{1}$, Dušan Dobromirov ${ }^{2}$, Mladen Radišič ${ }^{3}$, \\ Aleksandar Takači ${ }^{4}$
}

\begin{abstract}
In situations where there is a lack of relevant information for proper decisionmaking, investors tend to be ambiguity-averse, opting for the probabilities with predictable outcomes. In cases where investors are faced with options without known probabilities, they tend to choose an option that will guarantee the most negligible loss. When faced with a diminutive loss, the investors will try to avoid these losses, even if that means exposing more resources to potential losses. Average down investment strategy can help to overcome losses faster while risking large amounts of resources, thus, showing investors' propensity for loss-aversion. However, stock trading under ambiguity is not rational behavior, and is closer to gambling than investing, even when faced with losses. The choice of average down as investment strategy can explain the effect that dominates during investment decision-making process when losses occur due to ambiguity. This paper presents
\end{abstract}

\footnotetext{
* Received: 06-07-2018; accepted: 14-12-2018

1 Teaching assistant, University of Novi Sad, Faculty of Technical Sciences, Trg Dositeja Obradovića 6, 21000 Novi Sad, Serbia. Scientific affiliation: corporate finance, behavioural economics, portfolio economics. Phone: +381 64 8086644. Fax: +381 21 459740. E-mail: ferencak@uns.ac.rs.Personal website: http://www.ftn.uns.ac.rs/n1861288157/miroslav-ferencak (corresponding author).

${ }^{2}$ Associate professor, University of Novi Sad, Faculty of Technical Sciences, Trg Dositeja Obradovića 6, 21000 Novi Sad, Serbia. Scientific affiliation: corporate finance, behavioural economics, portfolio economics. Phone: +381214852191. Fax: +38121459740. E-mail: ddobromirov@ uns.ac.rs. Personal website: http://www.ftn.uns.ac.rs/n1861291972/dusan-dobromirov.

3 Associate professor, University of Novi Sad, Faculty of Technical Sciences, Trg Dositeja Obradovića 6, 21000 Novi Sad, Serbia. Scientific affiliation: public finance, SME sector support, corporate finance. Phone: +38121 4852191. Fax: +38121459740.E-mail: mladenr@uns. ac.rs. Personal website: http://www.ftn.uns.ac.rs/n1861290114/mladen-radisic.

4 Full Professor, University of Novi Sad, Faculty of Technology, Bul. Cara Lazara 1, 21000 Novi Sad, Serbia. Scientific affiliation: statistical modelling, fuzzy logic, applied mathematics. Phone: +381214853631. Fax:+38121451403.E-mail: stakaci@uns.ac.rs.Personal website: http:// www.tf.uns.ac.rs/site/index.php/sr-lat/10-katedre/katedra-010/104-dr-aleksandar-takaci.
} 
the results of a research conducted in order to determine if investors will use average down strategy when there is a lack of information on the market, and the size of the loss when they will be willing to use it. Obtained results show strong probability of average down usage among the subject group, thus proving aversion to a sure loss. The relation between risk aversion and aversion to a sure loss is tested. The results show that there is no influence of risk aversion on choice to use average down investment strategy. The results and possible applications of the research are thoroughly discussed.

Key words: loss aversion, ambiguity aversion, risk aversion, average down, investment decision-making

JEL classification: G41, D91

\section{Introduction}

An individual as a financial decision-maker is susceptible to many internal and external effects that can be disruptive to their rational decision-making process. The expansion of behavioral finance in past years is an answer to the previous failures of financial models which were based on the type of a rational decision-maker, such as Modern portfolio theory and Efficient market hypothesis. Behavioral models of financial decision-making take psychological effects into account, thus presenting a more reliable model. However, the psychological effects that influence decision-makers are numerous and are still being discovered, and it is hard to include them all in one behavioral decisionmaking model. Prospect theory, first described by Tversky and Kahneman (1979), and Expected Utility theory, set up by Von Neumann and Morgenstern (1944) and further developed by Savage (1954), offer explanation for why theories that assume rational behavior of financial decision-makers do not provide expected results.

The domain of losses under ambiguity presents itself as one of the least researched domains of behavioral finance. Losses weigh heavily on the decision-makers and they are often prone to riskier behavior when confronted with losses. The question that this paper will tackle is: will decision-makers be willing to invest additional resources if their assets lose some of their value and if they do not possess relevant information for optimal decision-making, or will they merely acknowledge the losses accumulated and disinvest, which would be in line with ambiguity aversion (and common sense, when there is no vital information available to make a sound investment decision)? In order to obtain results and answer this question, willingness to use average down investment strategy as a known high-risk strategy was used. For more authentic results and experience of subjects, they needed to choose the stock by themselves, being given some information about their volatility. This step was important to establish endowment effect of subjects over stock that later lost value and were the object of average down. Given that results of stock 
choice can be taken as a sign of risk aversion, the relation between risk aversion and aversion to a sure loss was also examined.

Since professionals are aware that in order to make good investment decisions one must possess enough information on which to base one's decision, and that investment decisions without proper assessment should not be made (Virlics, 2013), the authors hypothesize that most of the subjects would either do nothing or even sell their investment at a small cost rather than risk further losses. With proven positive correlation between risk aversion and loss aversion (Goldstein et al., 2008), the authors also consider that more risk averse investors will exhibit stronger aversion to a sure loss and, under ambiguous surroundings, exhibit aversion to a sure loss over ambiguity aversion, as suggested by Kocher et al. (2018). In order to test these hypotheses, the authors present the most relevant literature and research in the field of financial decision-making, with emphasis on psychological influences on financial decision-making. New methodology for research was developed using previously presented researches. The results of the research are presented, together with the comparison with previous results and potential implications and relevance. Conclusion provides highlights of the research along with the plans and guidelines for further research on this topic.

\section{Literature review}

While choosing investment strategies, decision-makers use various data to make decisions, but they are facing certain limitations. Decision-making is not just about evaluating the situation objectively, but also about facing subjective circumstances. Investors often do not have adequate information about the core problem; they do not have time or means to obtain information and often are incapable of understanding the given information. They are facing the difficulty of interpreting a bulk of information and a limited ability of counting (Simon, 1976). The concept of bounded rationality is gaining in importance in cases of time limitations for decision-making process or cost of information needed for sound decisions. In cases of bounded rationality, decision makers often opt for decision that will provide most satisfaction in given circumstances (and conversely, least regret), not the optimal decisions. Heuristic techniques are often used in the situations of bounded rationality, where the decision-makers use intuition for decision-making or repeat the same decisions that proved to be satisfactory in similar instances.

The presentation of information needed for decision-making and the presenter of that information is also a contributing factor to the decision-making process, regardless of the information presenter intentions and if he is active or not (Thaler and Sunstein, 2003). According to the principles of Libertarian Paternalism, presenters always influence decision-makers, either by chance or on purpose, by 
providing decision-makers with the reference point. As status-quo is often based in preferences, presenters should present reference point as ambiguously as possible in order not to interfere with the decision-making process. However, interference cannot be completely eliminated.

The market inefficiency can be in part contributed to the psychological traits of the decision makers. Classical finance put the perfect decision maker in its focal point. Humans are not perfect decision makers and are prone to different psychological effects, such as loss aversion, risk aversion, and different biases. Because of those effects stock prices often experience price changes that are not in accordance with their true value as they should be if taking efficient market hypothesis in consideration.

When investment decisions are made on the expectation base, decision-makers are influenced by real mathematical outcomes (grounded in mathematical and statistical based decision models) as well as subjectively experienced changes in their surroundings. On the basis of this, studies of the influence on investment makers are conducted, aimed at interpreting how they could be applied to creating new models which will be used in future decision-making processes (Sando et al., 2012).

Loss aversion was first identified by Kahneman and Tversky (1979), where it was noted that losses loom larger than gains, and that the utility curve is convex in the domain of losses and concave in the domain of gains, and that it gets steeper for losses than for gains. Their subsequent research (Tversky and Kahneman, 1992) established cumulative prospect theory which encompassed both uncertainty and risk, together with explanation of different behavioral effects that can explain and influence loss aversion. In further researches (Kahneman, et al., 1991), the utility for losses was approximately two to two and a half times higher than the utility for gains. Tom et al. (2007) found neural basis for loss aversion. Although there is common opinion that professionals exhibit less loss aversion, Pope and Schweitzer (2011) found that professionals also exhibit loss aversion. Loss aversion represents itself in different states, however some authors argue that loss aversion is not so generally applicable as thought before and they found lack of loss aversion in different surroundings, most notably in the case where differences between gains and losses were small (Erev et al., 2008; Mukherjee et al., 2017).

Risk aversion represents the preference of decision maker for certain outcomes over uncertain outcomes. When comparing stocks with different volatility, loss averse investors will choose stock that have low volatility. Goldstein et al. (2008) found that there was a strong correlation between loss aversion and risk aversion among their subject group. Also, myopic loss aversion can lead to risk taking behavior when information is scarce (Thaler et al., 1997). Under loss domain, decision makers tend to be risk seeking, trying to minimize their losses (Kahneman and 
Tverksy 1979). The goal of decision-makers under loss domain becomes to avoid loss regardless of additional risks he could be exposed to.

Average down as investment strategy in academic literature is almost nonexistent. The only relevant research on this topic was done by Brown et al. (2005) who found that average down was seldom used by professional traders. Their results also showed that average down was used only on individual security level. It is interesting to note that their findings discovered that professional investors aimed for previous stock prices when executing average down strategy, aiming to make gains in what would otherwise be return to status quo.

\subsection{Behavioral influences}

Endowment effect is a psychological effect closely related to loss aversion. Owners of goods, even recent ones, evaluate goods in their possession as more valuable than other goods of similar value. Endowment effect is exhibited by a difference in valuation of goods between owners of goods (Willingness to accept - WTA) and those that do not own those goods (willingness to pay - WTP). In research by Kahneman et al. (1991) the ratio between the WTP and the WTA was 2 and endowed subjects were unwilling to sell. The more recent studies are showing that endowment effect on the stocks exist, even in the case of inherited stocks (Santosh et al., 2018; Nofsinger, 2001). While endowment effect has been noted among inexperienced traders, the endowment effect among experienced traders is likely to be less of an issue, although it can be observed as well, since professional traders see trades as potential income (Koszegi and Rabin, 2006). With that in mind, it should be taken into consideration that traders on the stock market can manifest endowment effect, even with the knowledge and professional skills that they possess. Although it is considered that endowment effect is caused by loss aversion, Morewedge et al. (2009) consider that endowment effect is caused by mere ownership, and not loss aversion.

Status quo bias is another behavioral effect tightly explored with loss aversion. Decision makers should only be influenced by the preference-relevant features according to the rational choice model, and the way of presentation of alternatives and their order of presentation shouldn't affect the outcome of the decision-making process. This bias also shows the effects that Libertarian Paternalism principles can have on decision-making process. According to Samuelson and Zeckhauser (1988), status quo is always an option in reality, thus doing nothing or sticking with previous choices even when alternatives are presented is possible. They found that majority of their subjects were exhibiting status quo bias, both in situations where they presented alternatives with and without framing. The status quo bias in stock trading was investigated by Brown and Kagel (2009) who found the existence of status quo bias among traders on simplified markets. 
Disposition effect explains the phenomenon in which investors tend to keep their losing stocks longer that stocks that are gaining value in their portfolio (Odean, 2002; Frazzini, 2006). Combining disposition effect with stock momentum can have larger consequences. In their research, Jegadeesh and Titman (1993) found that stocks that performed well in the past will continue to perform well in the future, while stock that lost value in the past will continue to do so. Taking into consideration stock momentum, disposition effect is hard to explain as investors knowing about stock momentum should keep winning stock and sell losing ones, but most of the investors do the opposite. The reason why investors keep the losing stocks longer period is attributed to the prospect theory and loss aversion, in particular to the convexity of loss aversion and the convexity of the utility function under loss drive investors into risk seeking behavior (Shefrin and Statman, 1985). The risk seeking behavior of the investors is manifesting through the holding of the losing stocks with the idea that it will gain in value later.

Barberis and Xiong (2012) argue that disposition effect is a consequence of realization utility. According to realization utility, investors derive utility directly from gains relative to purchase price when selling assets. Investors are experiencing every stock acquisition and sale of the same stock as an episode in their trade and take utilities from those episodes. The rise in stock price over the purchase price will incite investors to sell stocks, while they will keep stocks whose price is under the purchase price. However, under that assumption, nobody would be willing to sell stocks when they are losing value, which is obviously not the case in reality. Ingersoll and Jin (2013) found that, given S-shaped utility, the investors would be willing to sell in case that there is a reinvestment possibility and that it is normal to sell losing stocks at some point.

The reason for holding on to the losing stocks can be sunk-cost fallacy. Sunkcost fallacy is manifested in tendency to continue endeavor in which some of the resources were committed, with underlying reason as to appear that those resources were not used wastefully (Arkes and Blumer, 1985). The costs that already occurred should have no influence on further decision-making, yet its existence was established in different studies (Arkes and Ayton, 1999; Strough et al., 2008; Phillips et al.,1991). According to Friedman et al. (2007), there are two distinct psychological mechanisms that can trigger sunk-cost fallacy: self-justification and loss aversion. Self-justification influences decision-makers to make further investments or to adjust their beliefs in order to avoid the admission of the mistake that they have made. Loss-aversion prompts decision-makers to make further investments with negative incremental return if there is a chance to recover or make small positive return. Although sunk-cost fallacy is established, it can be noted that there is a lack of proof that investors, as decision makers, are willing to invest more if there is a chance for a positive return. The existence of the effect where decisionmakers show willingness to invest more in a losing stock in order to obtain small 
gains if investment returns to its previous (reference point) value while risking possibility of larger losses if the falling trend continues, rather than accepting small losses, will be called aversion to a sure loss.

\subsection{Risk, uncertainty and ambiguity}

Risk represents state where the outcomes of actions are known with a probability of their occurrence. Besides certainty, which is hard, if not impossible, to attain, state of risk is a desired state for a decision-maker. Uncertainty presents risk with a lesser degree of confidence in the probabilities of the occurrences. Under uncertainty, the assigned probabilities are subjective. We can define ambiguity as a total uncertainty, or Knightian uncertainty, where the investors are not able to give any probabilities on occurrences. Ambiguity is the least wanted state of decision-making for the investors, which can also explain the existence of the ambiguity aversion, which states that people prefer known probabilities even if it brings less potential income.

On the stock exchange we can argue that there is either uncertainty or ambiguity state. Professional stock traders work in uncertain surroundings, since they should be able to predict the movement of stock prices with a certain degree of confidence. On the other hand, unsophisticated investors often don't possess enough skills and knowledge to assess the prices and their future directions and are mostly dependent on the stock market sentiment that don't need to be rooted in reality. Because of that it can be said that unsophisticated investors work in ambiguous environments.

Ambiguity aversion was first described by Ellsberg (1961) who, with his experiment with Ellsberg urns, found that decision-makers prefer reaching decisions with known probabilities over decisions with unknown probabilities. The results showed that decision-makers are ambiguity-averse in a way that they tend to choose smaller gains with known probability over bigger gains without known probability. According to Trautmann et al. (2008), one of the reasons for ambiguity aversion is fear of negative evaluation by others (FNE), where ambiguity aversion disappears in cases when preferences are private information of individuals and not subjected to a wider audience, which was the case in this research. Research by Roca et al. (2006) shows that decision-makers can become ambiguity-seeking because of the status quo bias.

\section{Research methodology}

The research was conducted using an online questionnaire tool, which was also used to collect results. Only one response per subject was allowed. To prevent ballot stuffing email accounts, participants were required to log into the questionnaire. Eighty-nine subjects participated in this survey and we didn't leave out any single result due to the infraction of the process. The subjects were motivated to participate 
in the survey by the possibility to experience new and important factors that drive decision making in the domain of their field of studies and, for most of them, their field of work. In order to qualify, subjects needed either to have formal financial education received at university (courses concerning stock market fundamentals, trading methods, stock appraisals, technical analysis), or stock market experience, either real or through some form of simulation. Majority of the subjects were graduated students from University of Novi Sad, Serbia, younger than 30 years of age that fulfilled both requirements.

The reason why participants with financial education background were chosen for this research was that the subjects should know the basic principles of stock exchange in order to better understand the problem that they were given. As decision for stock trading should be made by obtaining and processing large amounts of financial information, this composition of subject group should be able to give better insight than the unsophisticated investor. As ambiguity is the least desired state in the stock market, sophisticated investor should know that making investment decision under ambiguity is not rational behavior. In ambiguous surroundings, sophisticated investors are on the same level as unsophisticated investors, because their financial expertise cannot influence their decision-making. The sound reaction from sophisticated traders would be to stop investing and wait for further information in order to make the right decisions, which was tested in this experiment.

At the beginning of the experiment, subjects were supposed to choose between three different stocks valued at the same price. The difference between the stocks was its potential volatility, where stock A had low potential volatility (small potential gains and equally small potential losses), stock B had medium potential volatility and stock $\mathrm{C}$ had high potential volatility (high potential gains and equally high potential losses). Volatility of each stock was presented to the subject, and they were supposed to choose according to their preference to volatility. The choice of the subjects is important because it established two things:

1. It showed the attitude towards risk of each subject;

2. The action of choosing stocks endowed them with stocks, because they spent some time deliberating and choosing the stock that will suit them the best according to the level of their risk aversion.

Endowment effect is an important part of the research, because it is established that it can influence decisions of investors, although we are not measuring endowment effect itself.

Average down was used as a tool to research the investors' decision making under ambiguity when losses occur. Average down is an operation on the stock market where the owner of the stock that lost value is buying more stocks of the same issuer as to get lower price of the stock in his portfolio. The reasoning for this operation 
is that the investor, by averaging down the prices of stocks in his portfolio, would be in better position to obtain gains if the price of the stock that he/her has in their portfolio starts gaining in value. For example, if the investor bought one stock for the price of $10,00 \$$ and he/she buys another stock of the same company at the new price of $9,00 \$$, the purchasing price for both stocks combined is $9,50 \$$, and if the price of the stock rises over $9,50 \$$ the investor will make gains. The only framing we used is the premise that there is expectation of the professionals that there will be a raise in price of the stock in question, without naming those professionals, and what is the profit that they can expect if the stock price returns to the purchasing price $(10,00 \$)$. The research used possibility to use average down investment strategy on portfolio consisting of one stock that lost value after a certain time in order to differentiate between ambiguity aversion and aversion to a sure loss. The graph of stock price movement that subjects have chosen was presented (the graph was the same for all stock, regardless of previous choice).

The drawback of this strategy is that, by buying more stocks of the same company under new, lower price, the investor is exposed to larger monetary losses if those stocks continue losing value, which, by referring to the stock momentum, usually happens. By using average down strategy, investors are expressing aversion to a sure loss, because they commit large sum of money to a stock that will not necessary regain its value in order to faster recover lost assets. With dropping prices of stock in possession, average down strategy needs fewer monetary assets committed from the investor, but the break-even point is further away from the current price and it is harder to reach, although gains can be more significant.

Figure 1: Decision tree of the investors' decision-making process under ambiguity

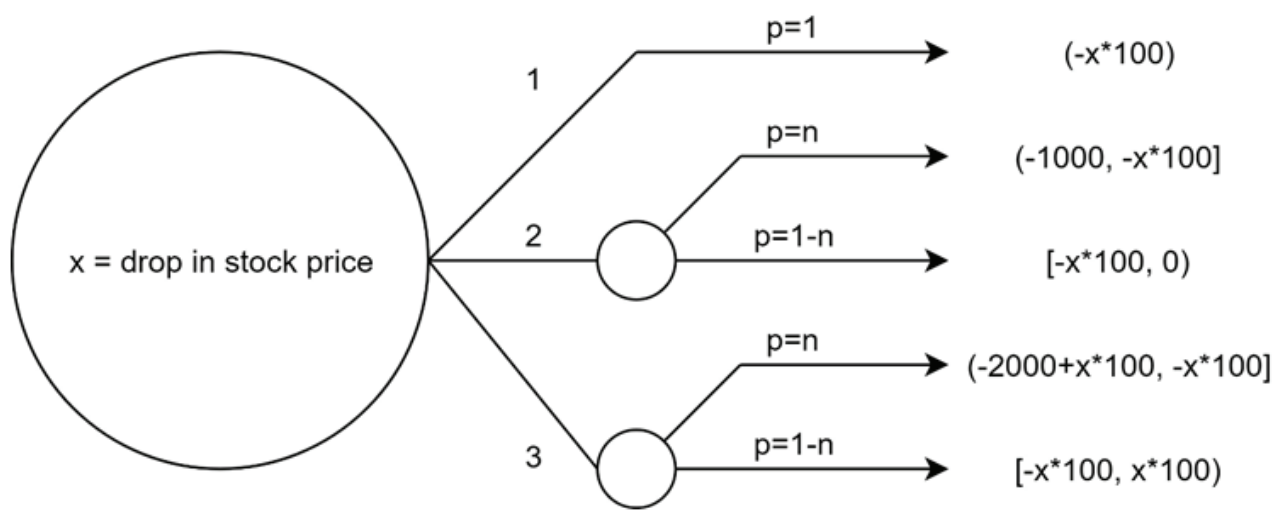

Source: Author's calculation

Figure 1. shows the relation between three potential options: certain loss (1), do nothing (2), and average down (3), of which latter two are under ambiguity, as well as absolute intervals of potential gains/losses of investors portfolio consisting of 
100 stocks if one would choose different option. Option 1 led to the certain loss with set amount of value $-\mathrm{x}^{*} 100$, where $\mathrm{x}$ is drop in stock price. Option 2 led to the new iteration of the question, where $\mathrm{x}$ was decreased by $0,50 \$$ and a new iteration was induced. Each new iteration lowered the current stock price by $0,50 \$$ and the same three options were given with adjusted values for the new stock price. This was done in order to imitate the pattern on the stock market, where the movements of the stock prices are gradual, not like in gambling which most of other researchers use, such as loss-aversion measurement method developed by Abdellaoui et al. (2016). As option 2 has two potential outcomes (stock price do not change or fall, stock price rise), in case of stock price falling or staying the same the range of losses for investor is anywhere between $-1000 \$$ (whole investment) and $-\mathrm{x}^{*} 100$ (drop in price of the investment). In case there is rise in stock price, but not above the previous status quo level (as it was suggested to the subjects), the range of losses is anywhere between $-\mathrm{x}^{*} 100$ and $0 \$$. Option 3 was to acquire 100 additional stocks of the same company, valued at current (lower price), which represents average down investment strategy. Choosing average down strategy also has two potential outcomes of stock price falling or stagnating, or stock price rising. In case of stock price falling or not changing, the range of losses is anywhere between $-2000+x * 100$ (whole original investment and new investment in order to execute average down strategy) and $-x^{*} 100$ (original drop in price of the investment). In case of the stock price rise, but not above the status quo level, the loss/gain range is anywhere between $-\mathrm{x}^{*} 100$ and $\mathrm{x}^{*} 100$ (gain in case of the price returning to status quo level). All options were presented to the subjects in clear and concise manner. If subject chose either option 1 or 3 , the experiment was stopped. If subjects chose option 2 ("do nothing"), another iteration was commenced, with a further drop in price of $0.50 \$$ of stock in subjects' possession.

Although the research was done in ambiguous environment, the probability in decision tree was given in order to differentiate the possibilities of the outcomes, where:

$$
p=n,
$$

when $\mathrm{n}$ is unknown for the possibility of the stock price growth, while:

$$
p=1-n,
$$

for a further stock price fall. The equations (1) and (2) give a total of 1, which means that stock prices can move in both directions. This is the same for both situations if there is no action by the investor or if he/she chooses to use average down as an investment strategy.

The results collected were statistically processed in order to acquire insight into subjects' decision-making process. Fisher's test was used to test the hypothesis that previous choice of the stock and aversion to a sure loss exhibited in that way does 
not have an influence on the choice of average down investment strategy when investors are faced with the loss under ambiguity. This statistical test is used by researchers to test the significance of the statistical comparisons (full name Fischer's exact test of independence) and is useful for categorical data (Connelly, 2016). While Upton (1992) argued for its use in 2x2 tables, Mehta and Patel (1983) developed an algorithm for performing Fisher's exact test for $r$ x $c$ contingency tables.

\section{Empirical data and analysis}

When faced with diminishing stock price, 78 subjects opted for average down investment strategy ( $87,64 \%$ of subject group), showing willingness to buy additional stocks in order to faster regain their lost assets, although it might lead them to additional losses. This result shows that subject groups exhibit signs of aversion to a sure loss. The first possible price at which subjects could opt for average down investment strategy was set at $9,00 \$$ and the average price at which subjects were willing to buy another set of stocks from those who opted for average down was $8,35 \$$ with median value set at 9 and standard deviation $\sigma=1,45$, meaning that the vast majority of subjects opted for average down investment strategy as soon as they were given the opportunity, which can be observed in Table 1 .

Table 1: Subject choice according to the current stock price

\begin{tabular}{|c|c|c|c|}
\hline Stock price & Average down & Sell & Do nothing \\
\hline $9,00 \$$ & 56 & 0 & 33 \\
\hline $8,50 \$$ & 9 & 1 & 23 \\
\hline $8,00 \$$ & 2 & 3 & 18 \\
\hline $7,50 \$$ & 0 & 1 & 17 \\
\hline $7,00 \$$ & 2 & 0 & 15 \\
\hline $6,50 \$$ & 0 & 0 & 15 \\
\hline $6,00 \$$ & 0 & 1 & 14 \\
\hline $5,50 \$$ & 0 & 0 & 14 \\
\hline $5,00 \$$ & 2 & 0 & 12 \\
\hline $4,50 \$$ & 5 & 0 & 7 \\
\hline $4,00 \$$ & 2 & 0 & 5 \\
\hline $3,50 \$$ & 0 & 0 & 5 \\
\hline $3,00 \$$ & 0 & 0 & 5 \\
\hline $2,50 \$$ & 0 & 0 & 5 \\
\hline $2,00 \$$ & 0 & 0 & 5 \\
\hline $1,50 \$$ & 0 & 0 & 5 \\
\hline $1,00 \$$ & 0 & 0 & \\
\hline
\end{tabular}

Source: Author's calculations 
Choosing option "do nothing" led to the new iteration of, with new stock price $0,50 \$$ lower than the previous one, while choosing either "average down" or "sell" led to the end of the survey. In each iteration, the price of the stock was $0,50 \$$ lower than in the previous one, and the same three options were available to subjects. That is why in Table 1. the number of subjects in the "do nothing" column is continuously decreasing. Five subjects did not opt for either 'average down' or 'do nothing' until the end of the survey.

Decision tree for the observed results can be seen in Figure 2. The results show that majority of subjects choose option 3 (average down) which would bring loss of anything between $1835 \$$ and $165 \$$ if the stock continues to lose its value or loss between $165 \$$ and gain of $165 \$$ if stock starts gaining value, with the unknown probabilities. The gain of $165 \$$ was chosen as the mindset of the subjects was framed for stock in their possession to return to their original value of $10,00 \$$, but the potential gains were much higher. One should note that this decision tree summarizes behavior patterns of all subjects who performed average down. Value $\mathrm{x}$ is any number higher than $-165 \$$.

Figure 2: Decision tree of the investors' decision-making process under ambiguity for calculated average worth of stock when an average down investment strategy was initiated

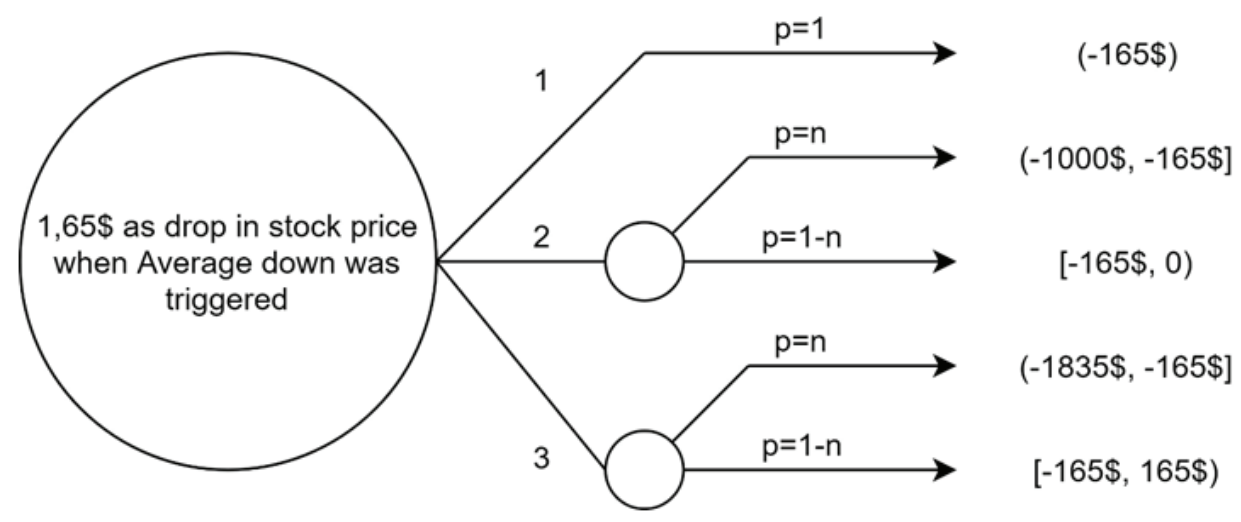

Source: Author's calculations

As the question was given in a manner where one choice would lead to loss with certainty and other choices with further ambiguity, it is safe to assume that those who opted for average down investment strategy displayed ambiguity seeking and loss aversion behavior, since the goal of their strategy was to evade sure loss and to invest further in the same stock with losing value and unknown future price direction of that stock. This implies that aversion to a sure loss is the dominant 
psychological effect in the case when stock in the possession of the investor starts losing value in ambiguous circumstances.

When presented with the choice of the three different actions with different levels of possible volatility, most of the subjects exhibited risk aversion, as can be seen in Table 2. Subjects were presented with the potential volatility of each stock. The majority of subject group chose stock A (least volatile) or stock B (with medium volatility), meaning that most of the group chose stocks that were less volatile, with less potential loss. 20 subjects chose volatile stock C, showing smaller levels of risk aversion.

Table 2: Distribution of subjects according to their stock choice

\begin{tabular}{|c|c|c|}
\hline Stock & Subjects & Percentage \\
\hline A & 37 & $41.57 \%$ \\
\hline B & 32 & $35.96 \%$ \\
\hline C & 20 & $22.47 \%$ \\
\hline Total & 89 & $100 \%$ \\
\hline
\end{tabular}

Source: Author's calculations

The distribution shows that $77 \%$ of the subjects have risk aversion up to a certain level, which is in accordance with previous researches. Majority of the group would rather buy a stock that has smaller prospect of gains, because they are afraid of potential losses that can occur. This result establishes that risk aversion exists among the subject group.

Table 3: Data needed to perform Fisher's Exact test

\begin{tabular}{|c|c|c|}
\hline Stock & Average down & Sell/keep \\
\hline A & 34 & 3 \\
\hline B & 28 & 4 \\
\hline C & 16 & 4 \\
\hline Total & 78 & 11 \\
\hline
\end{tabular}

Source: Author's calculations

For the second part of the research, we compared risk aversion and decision to use average down as an investment strategy. Fisher's exact test performed for $2 \times 3$ table (Table 3.) $(\mathrm{p}=0,46)$ shows that the choice of stock with which we obtained subjects preference towards risk aversion does not influence choice of average down investment strategy with 95\% confidence interval, showing that previous attitude towards risk aversion has no influence on aversion to a sure loss. Table 4. shows basic statistics for those subject who chose average down. 
Table 4: Statistics of subject who chose average down according to their stock choice

\begin{tabular}{|c|c|c|c|c|c|c|c|c|c|c|}
\hline $\begin{array}{c}\text { Stock } \\
\text { choice }\end{array}$ & N & Mean & $\begin{array}{c}\text { SE } \\
\text { Mean }\end{array}$ & StDev & Variance & Median & Mode & $\begin{array}{c}\text { N for } \\
\text { Mode }\end{array}$ & Skewness & Kurtosis \\
\hline A & 34 & 8.603 & 0.191 & 1.113 & 1.239 & 9 & 9 & 27 & -3.29 & 10.30 \\
\hline B & 28 & 8.304 & 0.269 & 1.423 & 2.205 & 9 & 9 & 18 & -2.31 & 4.29 \\
\hline C & 16 & 8.033 & 0.479 & 1.856 & 3.445 & 9 & 9 & 11 & -1.65 & 1.00 \\
\hline
\end{tabular}

Note: $\mathrm{N}$ - number of subjects which chose particular stock; Mean - average price of stock at which subjects opted to average down; SE Mean - Standard error of price; StDev Standard deviation of price; Median - median price of stock at which subjects opted to average down; Mode - price of stock at which most subjects chose to average down; N for mode - number of subjects who opted to average down on the mode price; Skewness measure of asymmetry of the distribution; Kurtosis - susceptibility to outliers.

Source: Author's calculations

It can be noted that mean and mode values of price at which subjects opted to trigger average down are the same, regardless of the previously exhibited ambiguity aversion, with somewhat larger dispersion of values for more volatile stocks, showing that the differences among the groups exist, but are minimal. Skewness and Kurtosis show that subjects who chose stocks with lower volatility tend to behave in similar pattern, where small and infrequent deviations from mode could be interpreted as outliers, showing strong homogeneity among subjects.

Although the scope of the research was to examine the existence of aversion to a sure loss among the subject groups and prevalence of either aversion to a sure loss or ambiguity aversion, the results can also be interpreted as a contribution to the disposition effect and sunk-cost fallacy.

\section{Results and discussion}

When put into ambiguous surroundings, investors tend to show risk aversion. However, it cannot be argued that investors exhibit risk aversion because they are afraid of losses, or have ambiguity aversion, or both. The results of the research show that, when faced with either ambiguity or loss, decision-makers prefer ambiguity and have aversion to a sure loss, even if that sure loss is $10 \%$ of the investment value, as shown in the research. The ambiguity aversion in this situation is almost completely discarded. The underlying reason for this can be the endowment effect that was established among the research group with stock selection, confirming, to some extent, results obtained by Santosh et al. (2018) and supporting Nofsinger (2001) claims. The authors found no relation between choice of stocks and aversion to a sure loss, meaning that previously exhibited 
level of risk aversion does not influence the usage of average down investment strategy and, consequently, loss aversion, which contradicts Goldstein et al. (2008) research. Subjects that didn't exhibit risk aversion also exhibited somewhat weaker aversion to a sure loss, although no certain conclusion could be derived from this experiment. The decisions made by the subject group cannot be considered as rational investment decisions under no consideration and support prospect theory.

The results obtained in this research are different from Brown et al. (2005) research, which can be attributed to the difference among subject groups. This result clearly identifies difference among professional and non-professional investors and shows that non-professionals are more susceptible to psychological influences such as aversion to a sure loss.

There are several implications of this research. First, this research shows that aversion to a sure loss can turn decision-makers from ambiguity averse into ambiguityseeking, diminishing their ambiguity aversion. Thus, in the case when information is scarce, aversion to a sure loss will have more prominent role than the ambiguity aversion. In underdeveloped markets and among the unsophisticated investors, which do not have necessary information (or if they don't know how to interpret them in the correct manner), investors are more prone to take the gamble under ambiguity with high potential losses in order to cut their current, albeit smaller, losses. The results also show that, when faced with losses, status quo bias is also diminished, contrary to the results of Samuelson and Zeckerhauser (1988) and Brown and Kagel (2009). However, our results support conclusions reached by Kocher et al. (2018).

This research shows that investors will behave irrationally when faced with losses in ambiguous surroundings, making decisions without proper information. Combined with the endowment effect and disposition effect, aversion to a sure loss under ambiguity can have devastating effects on investors, who will be willing to invest more in losing position in order to protect their investment when under ambiguous surroundings.

These results were obtained by just adding that there is an expectation that the price of the stock will go up, without further explanation of the information and the presentation of the carrier of the information. This shows that it is easy to manipulate the ambiguous market, even the investors with certain knowledge about the investment principles. There is certainly the need for corrective measures by the institutions that regulate the market in order to avoid the misuse of the ambiguous situations by individual advisors who can target investors owning assets that are losing value.

Overcoming irrational behavioral effects among traders is another important point, as aversion to a sure loss can be responsible for larger losses than among the investors without aversion to a sure loss. With the disposition effect and the fact that shares that have lost value tend to continue losing value (and vice versa), the 
stocks on the market are not evaluated correctly by the investors who hold those stocks, leading to the possibility of augmented losses. When combined with costsunk fallacy, these irrationalities can lead to further investments in assets that lose value. In order to compensate for the irrational behavioral effects, such as aversion to a sure loss, the need for a decision-making tool that will exclude behavioral effects is in order. However, the obstacle is that those tools are programmed by humans, which in turn can project their own psychological effects on the tool. The best way to avoid psychological effects on the investment decision-making is to use self-learning programs, which in turn needs to be supervised by a human individual in case of the non-programmed event.

Observing ambiguity to a sure loss in context of investment portfolio management would add another dimension to this research. It cannot be claimed that the results obtained in this research would hold if the stock that lose value would be one of the stocks in portfolio. However, taking into account disposition effect and the fact that substitutes cannot be eliminated from the market, even when not explicitly mentioned, it can be assumed that aversion to a sure loss can be observed for a stock that is a part of a larger portfolio.

\section{Conclusions}

Information is a basis for making a sound investment decision. The decision to invest in spite of lack of information should be treated as gambling. However, when losses occur, lack of information becomes insignificant problem, and the main task is to avoid the certain loss, as the research showed, contradicting previously set hypothesis that, when faced with lack of information, financial decision-makers will either maintain status quo or sell losing stocks. This cannot be treated as rational behavior among sophisticated investors, who rely on quantity and quality of information. With the use of average down investment strategy, existence of aversion to a sure loss was proven, with the majority of the subjects expressing willingness to invest more financial resources into assets that were losing value. Although there are several researches done in the field of sunk-cost fallacy, the ones that are specifically focused on the further investments under losses are scarce. Also, this research showed that there is no correlation between previously exhibited risk aversion and aversion to a sure loss under ambiguity, meaning that previous choices that decision-makers make and preferences that they exhibit have no influence on choices that decision-makers make when faced with the losses, with aversion to a sure loss being dominant effect over ambiguity aversion, which also contradict our hypothesis. This proves that even investors possessing certain degree of investment knowledge and experience tend to behave irrationally when losing, trading with stocks without any information needed in order to make sound investment decision in order to avoid the potential loss. Average down investment strategy can be used 
as a method for measuring aversion to a sure loss, as it combines effects that can appear during trades on the stock-exchange, such as loss aversion, endowment effect, disposition effect, ambiguity aversion and sunk-cost fallacy. This can be done through stock exchange simulation, so that all effects can be exhibited. While other models mostly disregard actual situations and mechanism of the stock market and thereby giving results that do not necessarily present the reality, stock exchange simulation can give more precise results, since most of the decisions made on stock exchange are not binary as in most researches. The authors are planning to expand the research in order to investigate the use of average down investment strategy in markets where the probabilities of stock price direction could be known with a certain degree of confidence, which would either support current conclusions that environment (ambiguity or uncertainty) is of little significance when investors are faced with losses or would show that environment can have influence on aversion to a sure loss under either ambiguity, uncertainty or risk. Further research on the use of average down investment strategy in the domain of uncertainty could yield approximate probability needed for loss acceptance, which in turn can be used for modeling and programming appropriate decision-making software which would use predictions of behavioral effects for better investment decision. There is also a need to see if the results obtained in this research would hold in portfolio situation.

\section{References}

Abdellaoui, M. et al. (2016) "Measuring Loss Aversion under Ambiguity: A Method to Make Prospect Theory Completely Observable", Journal of Risk and Uncertainty, Vol. 52, No. 1, pp. 1-20, doi: 10.1007/s11166-016-9234-y.

Arkes, H. R., Ayton, P. (1999) "The Sunk Cost and Concorde effect: Are Humans Less Rational than Animals?", Psychological Bulletin, Vol. 125, No. 5, pp. 591600, doi: 10.1037//0033-2909.125.5.591.

Arkes, H. R., Blumer, C. (1985) "The Psychology of Sunk Cost", Organizational Behavior and Human Decision Processes, Vol. 35, No. 1, pp. 124-140. doi: 10.1016/0749-5978(85)90049-4.

Barberis, N., Xiong, W. (2012) "Realization Utility". Journal of Financial Economics, Vol. 104, No. 2, pp. 251-271, doi: 10.1016/j.jfineco.2011.10.005.

Brown, A. L., Kagel, J. H. (2009) "Behavior in a Simplified Stock Market: the Status Quo Bias, the Disposition Effect and the Ostrich Effect", Annals of Finance, Vol. 5, No. 1, pp. 1-14. doi: 10.1007/s10436-007-0092-0.

Brown. S. J. et al. (2005) "Double or Nothing: Patterns on Equity Fund Holdings and Transactions", EFA Moscow Meeting Paper, doi: 10.2139/ssrn.555423.

Connelly, L. M. (2016) "Fisher's Exact Test”, Medsurg Nursing, Vol. 25, No. 1, pp. 58-61. Available at: <https://search.proquest.com/openview/83f08e2a2bd66b5a e46ceac7c1e82a5b/1?pq-origsite $=$ gscholar\&cbl $=30764>$. 
Ellsberg, D. (1961) "Risk, Ambiguity, and the Savage Axioms", The Quarterly Journal of Economics, Vol.75, No. 4, pp. 643-669, doi: 10.2307/1884324.

Erev, I., Eyal, E., Yechiam, E. (2008) "Loss Aversion, Diminishing Sensitivity, and the Effect of Experience on Repeated Decisions", Journal of Behavioral Decision Making, Vol. 21, No. 5, pp. 575-597, doi: 10.1002/bdm.602.

Frazzini, A. (2006) "The Disposition Effect and Underreaction to News" The Journal of Finance, Vol. 61, No. 4, pp. 2017-2046, doi: 10.1111/j.1540-6261. 2006.00896.x.

Friedman, D. et al. (2007) "Searching for the Sunk Cost Fallacy" Experimental Economics, Vol. 10, No. 1, pp. 79-104, doi: 10.1007/s10683-006-9134-0.

Goldstein, D. G., Johnson, E. J., Sharpe, W. F. (2008) "Choosing Outcomes versus Choosing Products: Consumer-Focused Retirement Investment Advice", Journal of Consumer Research, Vol. 35, No. 3, pp. 440-456, doi: 10.1086/589562.

Ingersoll, J. E., Jin, L. J. (2013) "Realization Utility with Reference-Dependent Preferences" The Review of Financial Studies, Vol. 26, No. 3, pp. 723-767, doi: 10.1093/rfs/hhs 116 .

Jegadeesh, N., Titman, S. (1993) "Returns to Buying Winners and Selling Losers: Implications for Stock Market Efficiency", The Journal of Finance, Vol. 48, No. 1, pp. 65-91, doi: 10.1111/j.1540-6261.1993.tb04702.x.

Kahneman, D, Tverksy, A. (1979) "Prospect Theory: An Analysis of Decision under Risk", Econometrica, Vol. 47, No. 2, pp. 263-292, doi: 10.2307/1914185.

Kahneman, D., Knetch, J. , Thaler, R. H. (1991) "Anomalies: The Endowment Effect, Loss Aversion, and Status Quo Bias", Journal of Economic Perspectives, Vol. 5, No. 1, pp. 193-206, doi: 10.1257/jep.5.1.193.

Kocher, M. G., Lahno, A. M., Trautmann, S. T. (2018) "Ambiguity aversion is not universal”, European Economic Review, Vol. 101, pp. 268-283, doi: 10.1016/j. euroecorev.2017.09.016.

Koszegi, B., Rabin, M. (2006) “A Model of Reference-Dependent Preference”, The Quarterly Journal of Economics, Vol. 121, No. 4, pp. 1133-1165, doi: 10.1093/ qje/121.4.1133.

Mehta, C. R., Patel, N. R. (1983) “A Network Algorithm for Performing Fisher`s Exact Test in $r$ x $c$ Contingency Tables", Journal of the American Statistical Association, Vol. 78, No. 382, pp. 427-434, doi: 10.2307/2288652.

Morewedge, C. K. et al. (2009) "Bad Riddance or Good Rubbish? Ownership and not Loss Aversion Causes the Endowment Effect", Journal of Experimental Social Psychology, Vol. 45, No. 4, pp. 947-951, doi: 10.1016/j.jesp.2009.05.014.

Morgenstern, O., Von Neumann. (1944) Theory of Games and Economic Behavior, Princeton: Princeton University Press.

Mukherjee, S. et al. (2017) "Is Loss-Aversion Magnitude Dependent? Measuring Prospective Affective Judgments Regarding Gains and Losses", Judgment and 
Decision Making, Vol. 12, No. 1, pp. 81-89, Available at: <http://journal.sjdm. org/16/16611/jdm16611.html>.

Nofsinger, J. R. (2001) Investment Madness: How Psychology Affects Your Investing... And What To Do About It, Upper Saddle River: Financial Times Prentice Hall.

Odean, T. (2002) "Are Investors Reluctant to Realize Their Losses?" The Journal of Finance, Vol. 53, No. 5, pp. 1775-1798, doi: 10.1111/0022-1082.00072.

Phillips, O. R., Battalio, R. C., Kogut, C. A. (1991) "Sunk and opportunity costs in valuation and bidding”, Southern Economic Journal, Vol. 58, No. 1, pp. 112-128, doi: $10.2307 / 1060037$.

Pope, D. G., Schweitzer, M. E. (2011) "Is Tiger Woods Loss Averse? Persistent Bias in the Face of Experience, Competition, and High Stakes", American Economic Review, Vol. 101, No. 1, pp. 129-157, doi: 10.1257/aer.101.1.129.

Roca, M., Hogarth, R. M., Maule, A. J. (2006) "Ambiguity Seeking as a Result of Status Quo Bias", Journal of Risk and Uncertainty, Vol. 32, No. 3, pp. 175-194, doi: 10.1007/s11166-006-9518-8.

Samuelson, W., Zeckhauser, R. (1988) "Status Quo Bias in Decision Making”, Journal of Risk and Uncertainty, Vol. 1, No. 1, pp. 7-59, doi: 10.1007/bf00055564.

Sando, S., Radišić, M., Dobromirov, D. (2012) "Emerging markets - Galapagos for Behavioral Financial Research", Actual problems of Economics, Vol. 12, pp. 459-469. Available at: <https://www.researchgate.net/publication/287338479 Emerging_markets_-_galapagos_for_behavioral_financial_research $>$.

Santosh, A., Balasubramaniam, V., Ramadorai, T. (2018) "Endowment Effects in the Field: Evidence from India's IPO Lotteries", The Review of Economic Studies, Vol. 85, No. 4, pp. 1971-2004, doi: 10.1093/restud/rdy014.

Savage, L. J., (1954) The Foundation of Statistics, New York: John Wiley and Sons.

Shefrin, H., Statman, M. (1985) "The Disposition to Sell Winners Too Early and Ride Losers Too Long: Theory and Evidence", The Journal of Finance, Vol. 40, No. 3, pp. 777-790, doi: 10.1111/j.1540-6261.1985.tb05002.x.

Simon, H., (1976) Administrative Behavior, New York: Free Press.

Strough, J. et al. (2008) "Are Older Adults Less Subject to the Sunk-Cost Fallacy than Younger Adults?", Psychological Science, Vol. 19, No. 7, pp. 650-652, doi: 10.1111/j.1467-9280.2008.02138.x.

Thaler, R. H., Sunstein, C. R. (2003) "Libertarian Paternalism”, American Economic Review, Vol. 93, No. 2, pp. 175-179, doi: 10.1257/000282803321947001.

Thaler, R. H. et al. (1997) "The Effect of Myopia and Loss Aversion on Risk Taking: An Experimental Test", The Quarterly Journal of Economics, Vol. 112, No. 2, pp. 647-661, doi: 10.1162/003355397555226.

Tom, S. M. et al. (2007) "The Neural Basis of Loss Aversion in Decision-Making under Risk" Science, Vol. 315, No. 5811, pp. 515-518, doi: 10.1126/science. 1134239. 
Trautmann, S. T., Vieider, F. M., Wakker, P. P. (2008), "Causes of Ambiguity Aversion: Known versus Unknown Preferences", Journal of Risk and Uncertainty, Vol. 36, No. 3, pp. 225-243. doi: 10.1007/s11166-008-9038-9.

Tversky, A., Kahneman, D. (1992) "Advances in Prospect Theory: Cumulative Representation of Uncertainty" Journal of Risk and Uncertainty, Vol. 5, No. 4, pp. 297-323, doi: 10.1007/BF00122574.

Upton, G. J. G. (1992) "Fisher`s Exact Test” Journal of Royal Statistical Society, Vol. 155, No. 3, pp. 395-402, doi: 10.2307/2982890.

Virlics, A. (2013) "Investment Decision Making and Risk", Procedia Economics and Finance, Vol. 6, pp. 169-177, doi: 10.1016/S2212-5671(13)00129-9. 


\title{
Averzija prema sigurnom gubitku: pretvaranje ulagača u kockare
}

\author{
Miroslav Ferenčak ${ }^{1}$, Dušan Dobromirov ${ }^{2}$, Mladen Radišić ${ }^{3}$, Aleksandar Takači $^{4}$
}

\begin{abstract}
Sažetak
U situacijama u kojima ne postoji odgovarajuća količina informacija dovoljna za proces donošenja odluka, ulagači iskazuju averziju prema neizvjesnosti birajući opciju s poznatom vjerovatnošć ishoda. Kada su suočeni s opcijama u kojima je vjerovatnost nepoznata, ulagači preferiraju opcije koje garantiraju najmanji gubitak. U slučaju da budu izloženi gubicima, ulagači će pokušati izbjeći gubitke, po cijenu izlaganja vlastitih sredstava dodatnim gubicima. Uprosječivanje cijene dionice kao investicijska strategija može doprinjeti bržem prevladavanju gubitaka, prikazujući na taj način ulagačev odnos ka gubitku. U uvjetima neizvjesnosti, trgovanje dionicama ne može se smatrati racionalnim ponašanjem, već kockanjem, čak $i$ u uvjetima ostvarivanja gubitaka. Izbor uprosječivanja cijene dionice kao investicijske strategije može pomoći u istraživanju dominantnih utjecaja prilikom procesa donošenja odluka od strane ulagača kada se ostvaruju gubici u uvjetima neizvjesnosti. Ovaj rad prezentira rezultate istraživanja spremnosti ulagača da primjene strategiju uprosječivanja vrijednosti dionica u slučaju nedostatka informacija na tržištu, kao i pri kojoj će cijeni dionica biti spremni primjeniti strategiju. Dobiveni rezultati ukazuju na veliku vjerojatnost korištenja startegije uprosječivanja cijene dionica, ukazujući na averziju prema sigurnom gubitku. Testiran je odnos između averzije prema riziku i averzije prema sigurnom gubitku. Dobiveni rezultati pokazuju da nema utjecaja averzije prema riziku na izbor strategije uprosječivanja cijene dionice. Rezultati i mogućnosti primjene su temeljito obrazloženi.
\end{abstract}

Ključne riječi: averzija prema gubitku, averzija prema neizvjesnosti, averzija prema riziku, bihejvioralne financije, uprosječivanje vrijednosti, donošenje odluka od strane ulagača

JEL klasifikacija: G41, D91

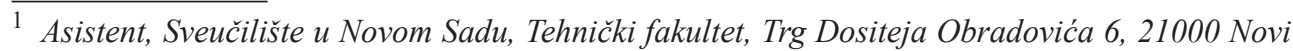
Sad, Srbija. Znanstveni interes: korporativne financije, bihevioralna ekonomija, ekonomija portfelja.Tel.: +381648086644.Fax:+38121459740.E-mail: ferencak@uns.ac.rs. Osobna web stranica: http://www.ftn.uns.ac.rs/n1861288157/miroslav-ferencak (osoba za kontakt).

2 Izvanredni profesor, Sveučilište u Novom Sadu, Tehnički fakultet, Trg Dositeja Obradovića 6, 21000 Novi Sad, Srbija. Znanstveni interes: korporativne financije, bihevioralna ekonomija, ekonomija portfelja. Tel.: +381214852191. Fax:+38121459740.E-mail: ddobromirov@ uns.ac.rs. Osobna web stranica: http://www.ftn.uns.ac.rs/n1861291972/dusan-dobromirov.

${ }^{3}$ Izvanredni profesor, Sveučilište u Novom Sadu, Tehnički fakultet, Trg Dositeja Obradovića 6, 21000 Novi Sad, Srbija. Znanstveni interes: javne financije, podrška sektoru malih i srednjih poduzeća, korporativne financije. Tel.: +381 21 4852191. Fax: +381 21 459740. E-mail: mladenr@uns.ac.rs.Osobnawebstranica:http://www.ftn.uns.ac.rs/n1861290114/mladen-radisic.

${ }^{4}$ Redoviti profesor, Sveučilište u Novom Sadu, Tehnički fakultet, Bul. Cara Lazara 1, 21000 Novi Sad, Srbija. Znanstveni interes: statističko modeliranje, fuzzy logika, primijenjena matematika. Tel.: +381214853631.Fax:+38121451403.E-mail: stakaci@uns.ac.rs. Osobnaweb stranica: http://www.tf.uns.ac.rs/site/index.php/sr-lat/10-katedre/katedra-010/104-dr-aleksandar-takaci. 